\title{
Clustering of the Economic Space of the Volga Regions
}

\author{
Napolskikh D.L. \\ Volga State University of Technology, \\ Yoshkar-Ola, Russia, \\ NapolskihDL@yandex.ru
}

\begin{abstract}
The article discusses the promising directions of clustering of the economic systems of the Volga region, as well as the localization of cluster initiatives in the economic space. The author's approach to the development of an integrated cluster model of the economic space of Russian regions is to consider innovation clusters as fundamental segments of the innovation economy. The article is devoted to the analysis of the spatial and economic conditions for regulating the processes of clustering and innovative development on the example of the Volga region. It is concluded that the current stage of the implementation of cluster policy in the Volga region is characterized by both multipolar and unipolar models of clustering the economic space. The tendencies of the formation of multicluster formations of intersectoral type, acting as poles of regional economic growth, are determined. Priority areas of interregional integration within the framework of joint cluster projects for each of the Volga regions are considered, areas of interaction with neighboring federal districts within the framework of the national cluster policy are determined.
\end{abstract}

Keywords - clustering of the economy, economic development of regions, Volga regions, interregional integration

\section{INTRODUCTION}

The current economic environment is creating the preconditions for improving the management of clustering processes within interregional economic systems [1]. Interregional cluster integration is one of the additional factors for the socio-economic development of Russian regions, while the formation of inter-sectoral cluster formations in order to spread innovation and diversify production in priority areas of economic activity remains relevant [2].

A strategic approach to the implementation of state cluster policy in the Volga region involves the formation of several innovative clusters based on successful cluster initiatives leaders in the investment attractiveness of the world level [3].

At the same time, achieving global competitiveness presupposes the activation of the Volga regions that do not use the potential of this form of economic development, which partially solves the problem of low domestic demand in certain regions of Russia through interregional integration within the framework of joint cluster projects [4].
The absence at the level of the Volga macroregion as an integral strategy of regional integration within the framework of joint projects of cluster development (including intersectoral development) is a limiting factor in the socio-economic development of Russian regions [5].

\section{PROBLEM STATEMENT}

Determining the optimal sectoral profile of cluster initiatives and their location in the economic space makes it possible to achieve the following prerequisites for sustainable socio-economic development of Russian regions:

- harmonization of the structure of the distribution of productive forces within the boundaries of federal districts and subjects of the Russian Federation;

- increasing the level of diversification of production within the framework of the implementation of the import substitution policy at the regional level;

- equalization of economic and social development of Russian regions.

To date, theoretical approaches to regulating clustering processes in the economic space are actively developing [6]. Accordingly, the need to take into account both all-Russian and Volga region problems of cluster development management determined the purpose of this work.

\section{RESEARCH QUESTIONS}

It seems expedient to compile a list of both successfully functioning clusters and potential clusters for each region of the Volga region. No less important for the study is the visualization of the processes of clustering the economic space on the map. Determination of the main directions of interregional integration of the Volga regions within the framework of joint projects will help to explain the contradictions of cluster development.

\section{PURPOSE OF THE STUDY}

The purpose of the study is to determine the main promising directions of clustering the economic space of the Volga microregion. 


\section{RESEARCH METHODS}

The theoretical and methodological basis of the study is the concepts and hypotheses in the field of cluster theory, theory of spatial development $[7,8]$. The solution of the set scientific tasks required the use of such general theoretical research methods as abstraction and concretization, analysis and synthesis, induction and deduction, comparison and opposition. The methodological toolkit of such areas of scientific thought as economic geography and regional economics was used. The solution of these problems requires the use of the following scientific methods: historical, economic and statistical, comparative and systems analysis; systematization of the analyzed regional economic systems, clusters and their elements; zoning, cartography, etc.

\section{FINDINGS}

In the course of analyzing the sectoral aspects of clustering the economy of the Volga region, priority directions of clustering were identified for each of the regions.

Republic of Bashkortostan. The Ufa agglomeration is a clustering center for the economy of the Republic of Bashkortostan. Oktyabrsky, Sterlitamak, Beloretsk are also identified as major centers of economy clustering.

The following clusters are identified as promising for the economic development of the region:

- Oil cluster. This cluster is located in the OktyabrskyTuymazsky industrial hub.

- Petrochemical cluster. It is located on the territory of the Sterlitamak (South Bashkir) agglomerationagglomeration.

- Aviation cluster. The center of the cluster is the monoterritory of Kumertau, the main participants are also located on the territory of the Ufa agglomeration.

- Energy cluster. It is located on the territory of the Ufa agglomeration.

- Metallurgical cluster (cluster center - Beloretsk monoterritory).

- Cluster of innovative biochemistry. It is located on the territory of the Ufa agglomeration.

Thus, the transformation of the economic space of the Republic of Bashkortostan based on the clustering of production has the following features. Let us emphasize the multipolarity of cluster processes in the republic (agglomeration of clusters) and the possibility of forming multi-cluster formations on the basis of the integrating role of the Ufa agglomeration. The scheme for the integration of promising clusters in the region developed by the author is shown in Fig. 1.

We note the key transport position of the republic in the Urals and the possibility of economic integration with other regions at the following key points: with the Samara region the Oktyabrsko-Tuymaz industrial hub (oil - Machine-building cluster), with the Chelyabinsk region - the Beloretsk industrial hub (metallurgical cluster), with the Orenburg region Sterlitamak agglomeration (petrochemical cluster) and Kumertau industrial hub (aviation cluster), with the Republic of Tatarstan - Agidel logistics hub.

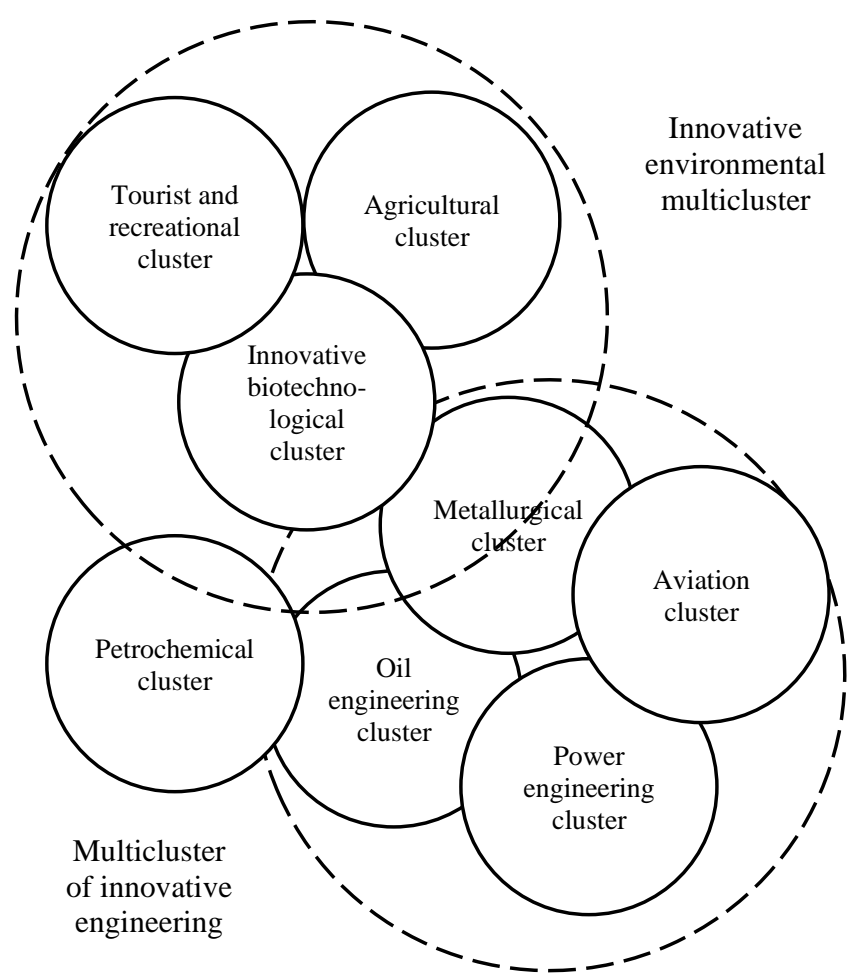

Fig. 1. Integration of promising clusters of the Republic of Bashkortostan into multi-cluster formations (developed by the author)

Orenburg region. The Orenburg and Orsk-Novotroitsk agglomerations are the centers of cluster processes in the regional economy. Buzuluk is also highlighted as a major center of economy clustering.

The following clusters have been identified as promising for the economic development of the region: the petrochemical cluster (location - the cities of Orenburg, Buzuluk), the oil and gas cluster of the Orenburg region (location - the cities of Orsk, Orenburg, Buzuluk), metallurgical. cluster of the Orenburg region (localization - the cities of Orsk, Novotroitsk, Gai), an energy cluster (localization of the city of Mednogorsk, Orenburg), an agro-industrial cluster (distributed over the region with centers in Orenburg and the Sol-Iletsk district).

Thus, the transformation of the economic space of the region based on the clustering of production has the following features. We note the key border position of the region with the Republic of Kazakhstan and the possibility of forming border clusters with industrial hubs Aktobe and Uralsk. Possibility of economic integration with other regions in the following key points: with the Samara region - the industrial hub Buzluk, with the Chelyabinsk region - the Orsk-Novotroitsk agglomeration, with the Republic of Bashkortostan-Orenburg agglomeration. We emphasize the multipolarity of cluster processes in the republic (merging of clusters) and the possibility of the formation of multi-cluster formations. A prospective scheme for the formation of multiclusters for the Orenburg region is shown in Fig. 2.

The Republic of Tatarstan. The center of the clustering processes of the economy of the Republic of Tatarstan is the special economic space "Volgo-Kama megapolis", the synergy of three agglomerations of Tatarstan: Kazan, Kama and Almetyevsk, which act as the main centers of clustering. economy of the region. The Kama innovation-territorial 
industrial cluster "Innokam" was created in 2012 and is the largest innovative multicluster in the Russian Federation. The main industry segments of this multi-cluster entity are: oil refining. petrochemicals, production of cars and auto components, robotics and IT technologies. The following clusters, which are in close scientific and industrial interaction, have also been identified as promising for the economic development of the region: machine-building cluster, IT cluster, furniture cluster, food cluster; tourist and recreational clusters of Tatarstan.

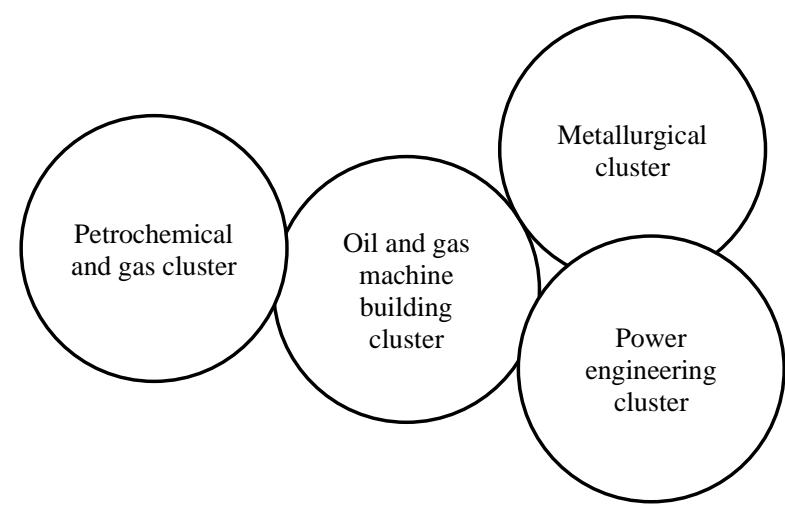

Fig. 2. Integration of promising clusters of the Orenburg region into multicluster formations (developed by the author)

We note the key transport position of the Republic at the intersection of key transport corridors:

- North-South Corridor: Krasnodar - Moscow - Saint Petersburg;

- East Corridor: Yekaterinburg - Krasnoyarsk Vladivostok;

- Central Corridor: Smolensk - Moscow Yekaterinburg.

The possibility of economic integration with other regions is possible at the following key points: with the Republic of Mari El and the Republic of Chuvashia - the Kazan clustering zone, the Kirov region and the Republic of Udmurtia - the Kama clustering zone, the Republic of Bashkortostan - the Almetyevsk clustering zone. A feature of the economic development of the region is the intersectoral nature of the clustering processes and the formation of multicluster formations based on the interaction of urban agglomerations.

Perm region. The Perm urban agglomeration is the center of cluster processes in the regional economy. The following clusters are identified as promising for the economic development of the region:

- Cluster of fiber-optical technologies "Photonics".

- Pharmaceutical cluster.

- The cluster of agricultural machinery.

- Cluster "Composites of The Kama Region".

- Information technology cluster.

All these clusters are located on the territory of the Perm urban agglomeration. Cluster of rocket engine building "Technopolis "Novy Zvezdny". Key cluster participants are located within the Perm urban agglomeration, including the territory Of the Novy Zvezdny Technopolis and the Motovilikha industrial zone.

We note the key transport position of the region at the junction of the Volga-Ural macro-region with the Urals proper. The following areas of economic integration are highlighted: the formation of interregional multicluster formations with clusters localized in the Republic of Udmurtia and the Sverdlovsk region, as well as with the Kama innovative cluster of the Republic of Tatarstan.

The Republic of Udmurtia. The center of the regional economy clustering processes is the territorial system of Izhevsk (the cities of Izhevsk, Votkinsk, Sarapul). A distinctive feature of the processes of clustering the economy is their intersectoral focus within the framework of the InnovationTerritorial-Engineering Cluster of the Udmurt Republic. The anchor enterprise of the cluster is the Kalashnikov concern. In addition to the defense industry, the cluster unites production in the following areas of economic activity: production of cars and auto components, information and communication technologies, metallurgy and metalworking, microelectronics and instrument making, production of new materials, production of rubber and plastic products.

Possibility of economic integration with other regions in the following key points: Kirov region - Vyatskiye Polyany (defense industry), with the Republic of Tatarstan -Agryz region and Kama clustering zone (Kama innovation cluster "Innokam"), Perm region - Tchaikovsky industrial complex. hub (Tchaikovsky District of the Perm Territory), which is part of the Izhevsk Investment Agglomeration.

Kirov region. The center of cluster processes in the regional economy is the Kirov monocentric agglomeration. A distinctive feature of the cluster policy of the Kirov region is the formation of regional specialization based on multi-cluster education in the field of innovative biotechnology, the core of which is the following cluster initiatives: the biopharmaceutical cluster "Vyatka-biopolis" and the biotechnology cluster. Kirov region. The forestry cluster and the tourist and recreational cluster are also identified as promising areas for clustering the economy of the Kirov region (Fig. 3)

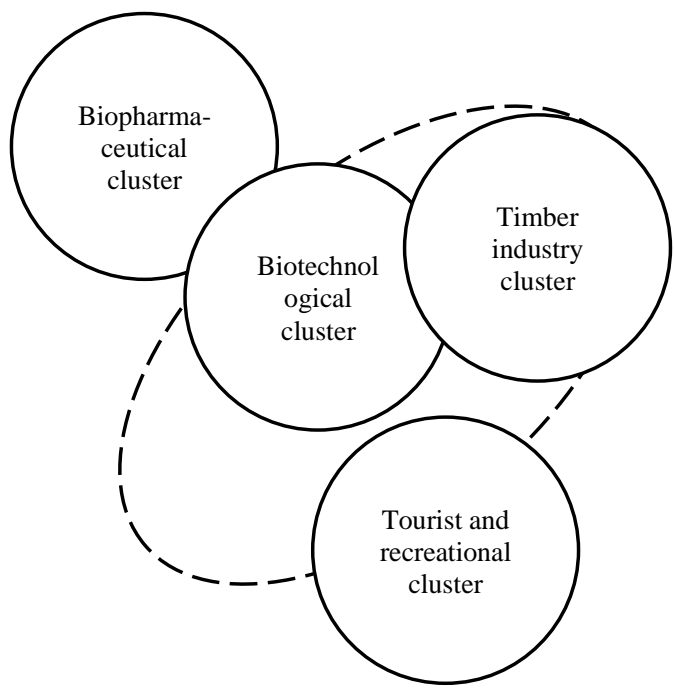

Fig. 3. Integration of promising clusters of the Kirov region into a multicluster (developed by the author) 
Mari El Republic. The center of clustering of the republic's economy is Yoshkar-Ola; enterprises of the selected clusters are also located in other regions of the republic.

There are no institutional cluster initiatives in the region. The following potential protoclusters of the RME have been identified: Innovative cluster of forestry, woodworking and reforestation, innovative cluster of agrobiotechnologies, Innovative cluster of instrumentation, electronics and information technologies of the Republic of Mari El.

Potential areas of cluster development in Mari El are integration with clusters located in the cluster development zone of Kazan, as well as the Republic of Chuvashia is a promising area for integration and formation of interregional clusters (for example, the Association "Innovative territorial electrical cluster of the Russian Federation "Chuvash Republic").

The Chuvash Republic. The clustering center of Chuvashia is the Cheboksary agglomeration, the centers of cluster development are also located in the cities of Shumerlya and Kanash. There is one developed innovative cluster in the region - the innovative territorial electrotechnical cluster of the Chuvash Republic.

Other cluster initiatives that have the potential to form growth points in the Chuvash Republic include the chemical cluster (Novocheboksarsk, part of the Cheboksary agglomeration), the transport engineering cluster (Kanash) and the Biopark cluster (Shumerlya).

As areas of interregional cluster integration, let us single out the already mentioned areas of interregional cooperation with the republics of Mari El and Tatarstan.

Nizhny Novgorod region. The clustering centers of the regional economy are the Nizhny Novgorod agglomeration, as well as the cities of Sarov, Arzamas, Pavlovo and Zavolzhye. In the Nizhny Novgorod region, the Nizhny Novgorod industrial and innovative cluster in the automotive and petrochemical industries is well developed. Anchor companies of the cluster: GAZ Group, SIBUR-Neftekhim. The following cluster initiatives are also being successfully implemented in the region: Industrial cluster of the Nizhny Novgorod region, cluster of light industry, biomedical cluster, shipbuilding cluster, international IT cluster, Sarov innovations.

We note the high potential of the Nizhny Novgorod region for the implementation of cluster initiatives (clusters in the field of nuclear energy and biopharmaceuticals) and intersectoral industrial cooperation. The Nizhny Novgorod region is the most important region of the Volga region in terms of economic integration with the Central Federal District, including the Upper Volga and the Moscow Industrial District. The interaction of clusters of the territorial system Nizhny Novgorod - Arzamas - Sarov with the clusters of the Republic of Mordovia has a high potential.

The Republic of Mordovia. On the territory of the republic, two clusters with a narrow industry specialization are successfully functioning: the innovative cluster of Mordovia "Lighting Engineering and Optoelectronics" and the industrial cluster of Mordovia "Fiber Optics and Optoelectronics". The cluster enterprises are located in the cities of Saransk (the center of cluster development of the region), Ardatov, Kadoshkino, Insar.
High organizational level of development of the innovation cluster of the Republic of Mordovia "Lighting Engineering and Optoelectronic Instrumentation", which can become the core of cluster formation in related industries, as well as the possibility of integrating the cluster with neighboring regions of the Volga region (Nizhny Novgorod, Penza and Ulyanovsk regions).

Penza region. The center of cluster development of the region is the Penza agglomeration. On the territory of the cluster, 4 successfully developing cluster initiatives have been formed: IT cluster (localized in Penza), Zarechensky cluster of technological integration (Zarechny, Penza agglomeration), engineering and production cluster "Biomed" (Penza), Penza instrument cluster "Security" (Penza). We note the high cluster activity of the region and the potential both for multicluster integration and for the implementation of cluster initiatives in such industries as confectionery, light and woodworking.

Saratov region. Saratov region is not very active in the field of institutionalization of protoclusters in the form of cluster initiatives. Saratov is a potential clustering center of the region. In this context, the implementation of interregional cluster projects with neighboring regions, in particular with the Penza region, is promising. We emphasize that the enterprises of the Saratov region are part of the industrial cluster "Composites without Borders", this trans-regional cluster unites enterprises of the Saratov Region, the Republic of Tatarstan and the Moscow Region. We also note the key geographical position of the Saratov region for integration into a single economic space of the Volga-Ural macroregion of the Lower Volga.

Samara region. The Samara region has a high level of cluster activity. the center of clustering in the region is the Samara agglomeration. The following effective clusters have been formed in the region: an innovative territorial aerospace cluster, an innovative territorial cluster of medical and pharmaceutical technologies and a cluster of the automotive industry of the Samara region.

These clusters constitute the innovative core of the region's economy and its clustering. We note the high potential of economic integration with the clusters of Ulyanovsk (Ulyanovsk-Avia cluster, Ulyanovsk automobile cluster, atomic-innovation cluster of the city of Dimitrovgrad) and Orenburg region (Buzuluk industrial hub).

Ulyanovsk region. The regional economy clustering center is the Ulyanovsk-Dimitrovgrad territorial system (the presence of a developed cluster in the city of Dimitrovgrad, the development of the Zavolzhskaya industrial zone and the port special economic zone of the Cherdaklinsky district). The region is distinguished by the presence of developed clusters: the Ulyanovsk-Avia cluster, the Ulyanovsk automotive cluster, the Dimitrovgrad nuclear innovation cluster. These clusters form the innovative profile of the region and serve as the scientific and technological core for the development of cluster initiatives in the region (nuclear medicine, instrument making and machine tool building, agro-industrial production).

The aforementioned economic integration of clusters in the Samara and Ulyanovsk regions, as well as with other regions of the Volga region, is of great importance for the economic development of the region due to its favorable geographical position in the Middle Volga region and developed transport infrastructure. 


\section{DISCUSSION}

The results obtained allow us to propose hypothetical directions for clarifying the Spatial Development Strategy of the Russian Federation [9]. In particular, add the Ulyanovsk region (Ulyanovsk-Dimitrovgrad) to the list of promising research and educational centers of economic growth in Russia. Also "raise the level" of Saransk from Group III to Group II, considering it as a promising development center that will contribute to the economic growth of the Russian Federation from 0.2 percent to 1 percent annually.

Based on the results obtained, which, of course, are of a controversial nature, it is possible to expand the scientific and practical discussion in relation to the selected research problem. In particular, it can be concluded that the goals and objectives of the strategic development of Russia were correctly selected within the framework of the innovative scenario of economic growth [10].

At the same time, it should be concluded that the implementation of cluster policy is insufficient for the innovative transformation of the economy of Russian regions [11].

We also note the concentration of these strategic documents on already industrial territories without due attention to the processes of interregional cooperation in order to equalize the pace of socio-economic development [12].

\section{CONCLUSION}

It is concluded that the Volga regions are characterized by significant differences both in the level of clustering of the economy and in the nature of cluster processes in the economic space of the region. The following regions with predominantly multipolar models of clustering economic space were identified: the republics of Bashkortostan and Tatarstan, the Nizhny Novgorod and Orenburg regions.

The rest of the Volga region is characterized by a unipolar clustering model centered in the urban agglomeration, which is the capital of the region. At the same time, the integrating role of the capital is also typical for regions with a multipolar clustering model, in particular, in the formation of multi-cluster formations of an intersectoral type.

It should be noted that in the regions under consideration, there are tendencies towards the formation of multi-cluster formations based on the integration of industries around developed clusters.

Among the potential multicluster formations, the following are highlighted:

- the Republic of Tatarstan - the integration of regional clusters within the framework of the strategy "Tatarstan 2030”,

- the Republic of Bashkortostan - an innovative ecological multicluster and multicluster of innovative engineering,

- the Udmurt Republic - Innovation-territorial engineering cluster,

- Orenburg region - Integration of industrial production of the region on the basis of a natural gas cluster,
- Kirov region - Multicluster of innovations and natural resources based on clusters of biotechnology and biopharmaceuticals,

- Nizhny Novgorod region - an industrial-innovative cluster in this field of automotive industry and petrochemistry,

- Republic Mordovia - clusters with related specializations in lighting, optoelectronics and fiber optics.

Also, for each of the regions of the Volga region, priority areas of interregional integration with neighboring regions on the basis of joint cluster projects have been identified. At the same time, speaking about the problem of the cohesion of the economic space of the Volga region as a macro-region, it is necessary to single out a number of clustering centers that play a connecting role. These clustering centers include the urban agglomerations of Kazan, Kama, Samara, Ufa and Sterlitamak.

\section{Acknowledgments}

This research was supported by Grant of Russian scientific Foundation no. 19-78-00056 "Cluster model of the Volga region development in the conditions of innovative economy".

\section{References}

[1] D. Radicic, D. Douglas, G. Pugh and I. Jackson, "Cooperation For Innovation And Its Impact On Technological And Non-Technological Innovations: Empirical Evidence For European Smes In Traditional Manufacturing Industries", International Journal of Innovation $\begin{array}{llll}\text { Management, } & 2019, & \text { vol. } & \text { 23(5). }\end{array}$ https://doi:10.1142/S1363919619500464

[2] M. Guerrero, F. Herrera and D. Urbano, "Strategic Knowledge Management Within Subsidised Entrepreneurial University-Industry Partnerships", Management Decision, 2019, vol. 57(12), pp. 3280-3300. DOI: https://doi:10.1108/MD-10-2018-1126

[3] F. Belloc, "Corporate Governance And Innovation: A Survey", Journal of Economic Surveys, 2012, vol. 26(5), pp. 835-864. DOI: https://doi:10.1111/j.1467-6419.2011.00681.x

[4] I. Basterretxea, J. Charterina and J. Landeta, "Coopetition And Innovation. Lessons From Worker Cooperatives In The Spanish Machine Tool Industry", Journal of Business and Industrial Marketing, 2019, vol. 34(6), pp. 1223-1235. DOI: https://doi:10.1108/JBIM-01-2018-0015

[5] S. Ziyadin, A. Omarova, R. Doszhan, G. Saparova and G. Zharaskyzy, "Diversification Of R And D Results Commercialization", Problems and Perspectives in Management, 2018, vol. 16(4), pp. 331-343. DOI: https://doi:10.21511/ppm.16(4).2018.27

[6] S. Arvanitis, N. Sydow and M. Woerter, "Is There Any Impact Of University-Industry Knowledge Transfer On Innovation And Productivity? An Empirical Analysis Based On Swiss Firm Data", Review of Industrial Organization, 2008, vol. 32(2), pp. 77-94. DOI: https://doi:10.1007/s11151-008-9164-1

[7] Y. Bae and H. Chang, "Efficiency And Effectiveness Between Open And Closed Innovation: Empirical Evidence In South Korean Manufacturers", Technology Analysis and Strategic Management, 2012, vol. 24(10), pp. 967-980. https://doi:10.1080/09537325.2012.724164

[8] L. El Iysaouy, N.E. El Idrissi, M. Tvaronavičiene, M. Lahbabi and A. Oumnad, "Towards Energy Efficiency: Case Of Morocco", Insights Reg.Dev., 2019, vol. 1(3), pp. 259-271. Retrieved from: www.scopus.com

[9] Spatial Development Strategy Of The Russian Federation For The Period Until 2025. Ministry of economic development of the Russian Federation, 2019. Retrieved from: https://www.economy.gov.ru/material/directions/regionalnoe_razvitie/st rategicheskoe_planirovanie_prostranstvennogo_razvitiya/strategiya_pro stranstvennogo_razvitiya_rossiyskoy_federacii_na_period_do_2025_go $\mathrm{da} /$ 
[10] The Concept Of Long-Term Socio-Economic Development Of The Russian Federation Until 2020 (2008). Ministry of economic development of the Russian Federation. Retrieved from: http://www.edqu.ru/upload/iblock/d08/3.1.2009.14.pdf

[11] T.V. Luzina, E.A. Dudareva, E.M. Akhmetshin, N.A. Prodanova, Y.S. Berdova and G.E. Emaletdinova, "International Legal Format For Trans Regionalisation Of Trade And Economic Partnership Within BRICS In
Global Development", Space and Culture, India, 2019, vol. 7(3), pp. 7685. DOI: https://doi:10.20896/saci.v7i3.508

[12] Forecast Of Long-Term Socio-Economic Development Of The Russian Federation For The Period Up To 2030 (2013). Ministry of economic development of the Russian Federation. Retrieved from: http://old.economy.gov.ru/minec/activity/sections/macro/prognoz/doc20 130325_06 